\title{
REVIEW
}

\section{Life history of American eel Anguilla rostrata: new insights from otolith microchemistry}

\author{
B. M. Jessop ${ }^{1, *}$, D. K. Cairns ${ }^{2}$, I. Thibault ${ }^{3}$, W. N. Tzeng ${ }^{4}$ \\ ${ }^{1}$ Department of Fisheries and Oceans, PO Box 1006, Dartmouth, Nova Scotia B2Y 4A2, Canada \\ ${ }^{2}$ Department of Fisheries and Oceans, PO Box 1236, Charlottetown, Prince Edward Island C1A 7M8, Canada \\ ${ }^{3}$ Département de Biologie, Université Laval, Québec, Québec G1K 7P4, Canada \\ ${ }^{4}$ Institute of Fisheries Science, College of Life Science, National Taiwan University, Taipei, Taiwan 106, ROC
}

\begin{abstract}
Temporal patterns in Sr:Ca concentration ratios of American eel Anguilla rostrata otoliths indicate variable patterns of residence in-and migration among-river, estuarine, and marine habitats. Annual growth rates, based on $\mathrm{Sr}$ :Ca habitat determinations, increase with increasing habitat salinity (fresh water < estuarine < marine) and increasing proportion of residence at higher salinities. Increased annual growth rate reduces the age at maturity because maturity is triggered by size rather than age. Our results highlight the importance of brackish and marine waters as areas of eel production. Most eels that recruit to fresh water do so as elvers but some (12 to $25 \%$ ) recruit as juveniles. After entering fresh water, between 23 and $100 \%$ of eels remain exclusively in fresh water. Most inter-habitat migrants make only one such movement before their spawning migration. Exclusively freshwater residence increases with distance upstream. Inter-habitat migrations may produce otolith checks that may be mistaken for annuli and increase the difficulty of age determination. Otolith growth periods may acceptably indicate freshwater or seawater habitat residency durations when the otolith (fish) growth rates in each habitat are similar but not if the growth rates differ greatly. Outlier Sr:Ca values may often depart substantially from a habitat norm but whether they represent a brief habitat transition is uncertain. Ignoring them potentially underestimates, while unnecessarily counting them overestimates, the frequency of inter-habitat movement. Research requirements include determination of the geographic extent and degree of periodic euryhaline migratory behaviour by American eels. Development of a simple, comprehensive residence and inter-habitat migration classification scheme would greatly assist the interpretation and comparison of otolith microchemistry studies.
\end{abstract}

KEY WORDS: American eel · Otolith · Microchemistry · Migratory behaviour

\section{INTRODUCTION}

Measurements, core-to-edge, of otolith $\mathrm{Sr}$ :Ca ratios of American eel Anguilla rostrata, in relation to microstructural features, have recently been used to investigate eel habitat residence, inter-habitat (fresh water, salt water) migration patterns and habitat-specific growth rates (Jessop et al. 2002, 2004, 2006, Morrison et al. 2003, Cairns et al. 2004, Daverat et al. 2006, Lamson et al. 2006). Otolith Sr:Ca studies have shown that the 3 temperate-zone species of anguillid eels ( $A$. anguilla, A. japonica, A. rostrata) are facultativelyrather than obligatively-catadromous and are remarkably plastic in habitat use (Tsukamoto \& Arai 2001, Daverat et al. 2006). American eels may inhabit marine, estuarine, and freshwater habitats during their continental phase, a diversity of habitat use that, coupled with migratory plasticity, has enabled American eels to occupy the most extensive range (over $10000 \mathrm{~km}$ of continental coastline between latitudes $\sim 7$ and $\sim 55^{\circ} \mathrm{N}$ ) of any fish in the Americas (Helfman et al. 1987, Edeline 2007). 
American eels spawn in the Sargasso Sea and the larval leptocephali are transported via the Gulf Stream along the Atlantic coast of North America (Tesch 1977). Following detrainment from the Gulf Stream to the continental shelf, the leptocephali metamorphose to glass eels that become pigmented elvers as they enter coastal waters during spring. After a continental growth (yellow eel) phase lasting for perhaps 3 to $>40$ yr (Helfman et al. 1987, Jessop 1987), yellow eels metamorphose to sexually-maturing silver-phase eels and begin their spawning migration to the Sargasso Sea, with sexual maturation occurring during the migration.

Otolith microchemistry enables reconstruction of the habitat residence and inter-habitat migratory history of individual eels via the positive relation between ambient salinity (and its Sr:Ca ratio) and otolith $\mathrm{Sr}$ :Ca ratio (Tzeng 1996, Campana 1999, Daverat et al. 2005). Although ambient molar Sr levels are almost 100 times greater in seawater than in fresh water, the molar ratio of $\mathrm{Sr}: \mathrm{Ca}$ in seawater is only about 4.8 times greater than in fresh water, and is the value most relevant to the relative rate of uptake by fish (Campana 1999). Habitat history reconstructions have confirmed 3 basic residence histories for American eels (marine, estuarine, fresh water) and a variety of inter-habitat migration patterns, depending upon the classification system used (Jessop et al. 2002, 2006, Cairns et al. 2004, Lamson et al. 2006, Thibault et al. 2007b). Seasonal (spring and autumn) migrations between estuary and river, both upstream and downstream, by portions of an eel stock (seasonal partial migration) are well known (Smith \& Saunders 1955, Medcof 1969, Jessop 1987, 2003) but analysis of the temporal change in otolith $\mathrm{Sr}$ :Ca ratio has enabled a more detailed understanding of the periodicity and duration of such movements (Daverat et al. 2006, Jessop et al. 2006). Seasonal migrations comprise both summer feeding and winter refuge migrations and serve to improve fitness and survival by, for example, improving feeding conditions, reducing predation and competition, and providing suitable overwintering habitat (Northcote 1978, 1984). Our use of the term 'migration' is consistent with that given by Lucas \& Baras (2001), where migration is a synchronized movement that is usually large relative to the average home range for that species and which occurs at specific stages of the life cycle, including migration for reproduction, feeding, and more appropriate habitat conditions. It may also be cyclical, seasonal, occur between habitats of different salinity, and involve only portions of a stock.
This review synthesizes recent advances in our understanding of the diversity of habitat use by American eels in Atlantic Canada, resulting from otolith microchemistry analysis, and also examines technical issues constraining the interpretation of such analyses.

\section{MATERIALS AND METHODS}

This review synthesizes information from the following publications: Jessop et al. (2002, 2004, 2006, 2007), Cairns et al. (2004), Daverat et al. (2006), Lamson (2006), Lamson et al. (2006), Thibault (2006), and Thibault et al. $(2007 a, b)$. All study sites are in the Gulf of St. Lawrence except for the East River, Chester, which is on the Atlantic coast of Nova Scotia (Fig. 1). Most eels sampled were yellow-stage juveniles but silver eels were obtained from the East River and the St. Jean River. Fishing methods varied among studies and included fyke nets, weirs, pots, rotary traps, and electrofishing.

In all studies, $\mathrm{Sr}: \mathrm{Ca}$ analyses were conducted on sagittal otoliths prepared in a similar manner and analyzed with similar procedures and equipment. $\mathrm{Sr}: \mathrm{Ca}$ concentration ratios were measured as weight percent (wt\%). After electron microprobe analysis (JEOL LXA8900R), otoliths were repolished and etched with $5 \%$

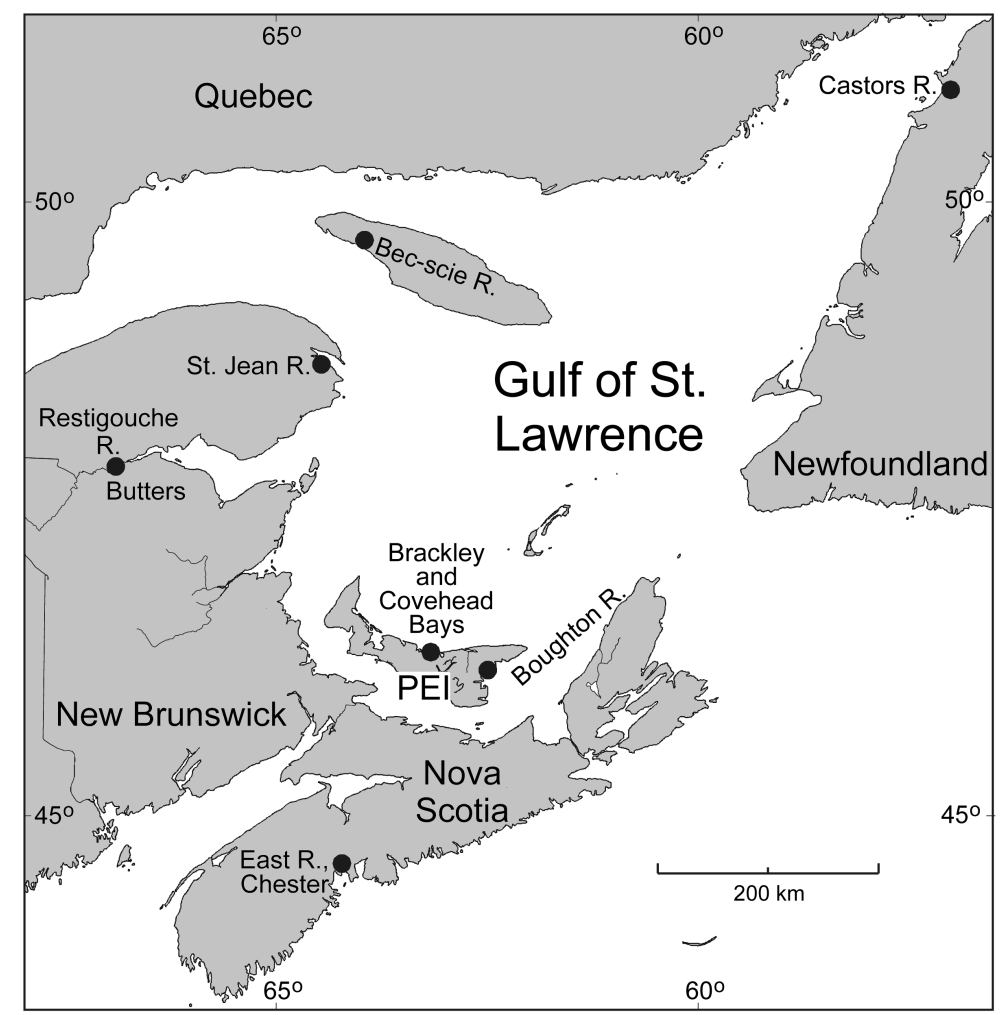

Fig. 1. Map of eastern Canada showing American eel otolith Sr:Ca ratio study sites 
EDTA to enhance the annuli for ageing. Oliveira (1996) validated the presence of annual growth rings in otoliths of the American eel. In Thibault et al. (2007b), the otoliths were stained with $0.01 \%$ toluidine blue after etching.

Habitat residence classification and the identification of inter-habitat movement for individual eels were based on the temporal change of otolith Sr:Ca ratio values relative to defined life history stages (Fig. 2a) and habitat (marine, estuarine, fresh water) reference values (Fig. 2b). Habitat classification schemes varied among studies but all distinguished one or more categories of residence in marine, estuarine, or fresh water habitats as well as inter-habitat migrants. The term 'salt water' includes both brackish and seawater salinities. Habitat assessments began either from the elver check or Age 1 yr annulus, depending upon the study. For eels collected in fresh water, only Jessop et al. $(2002,2004,2006)$ reported ambient water Sr:Ca ratios to assist interpretation of otolith Sr:Ca levels (Kraus \& Secor 2004).
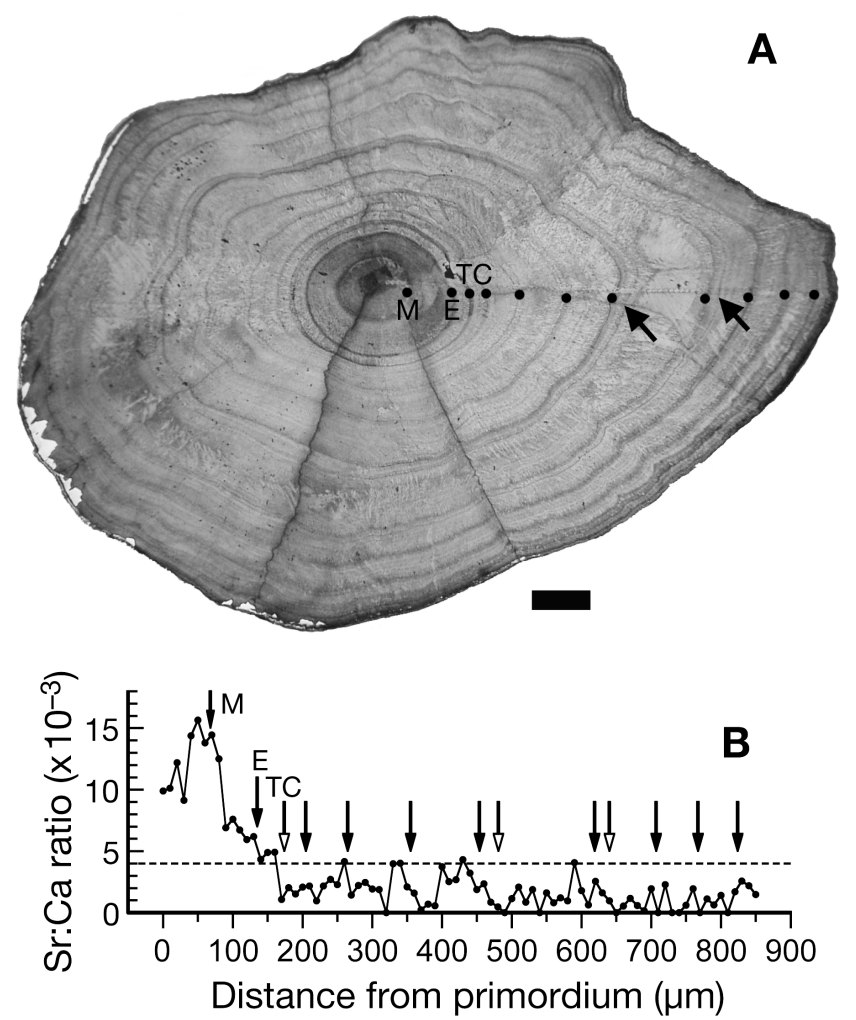

Fig. 2. Anguilla rostrata. (A) Sagittal otolith of yellow American eel (Eel 2-66, total length: $232 \mathrm{~mm}$, age: $8 \mathrm{yr}$ ) showing metamorphosis check (M), elver check (E), habitat transition check (TC) and annuli (remaining dots) and other checks (arrows) along the transect measured for $\mathrm{Sr}: \mathrm{Ca}$ ratio data. Scale bar = $100 \mu \mathrm{m}$. (B) Plot of Sr:Ca ratio data indicating metamorphosis, elver, and annuli (solid arrows) and habitat transition check and other checks (open arrows). Dashed line: habitat transition criterion (Sr:Ca $\left.=4 \times 10^{-3}\right)$. Source: Jessop et al. (2006)
Estimates of annual eel growth (rates) in relation to habitat salinity were based on back-calculated lengthsat-age under the 'body proportional hypothesis' (Francis 1990, Jessop et al. 2004, 2006, 2007, Lamson 2006, Thibault et al. 2007b). Growth rate estimates were typically restricted to a specific age so as to obtain experimental group sizes above a minimum and to minimize bias (over-representation of slow-growing eels at higher age groups) arising from faster-growing eels silvering and departing the river at an earlier age.

\section{RESULTS AND DISCUSSION}

\section{Habitat-residence classifications}

A variety of classification schemes have been proposed to describe the remarkable complexity of habitat residence and inter-habitat migratory behaviour shown by American (and other temperate anguillid) eels (Table 1). Classifications have variously accounted for habitat salinity, age (stage) of initial fresh water entrance, age of subsequent inter-habitat movements, direction of migration (upstream, downstream), and season of migration (spring, summer, autumn). The minimum classification consists of saltwater residents, freshwater residents, and inter-habitat migrants but elaborations of the latter group are often made. Some categories are special cases of a more general pattern. For example, Type 3a of Daverat et al. (2006) is a subset of the more general Type $\mathrm{IH}_{\mathrm{Sw}}$ while Types $3 \mathrm{~b}, \mathrm{c}, \mathrm{d}$ are subsets of Type $\mathrm{IH}_{\mathrm{Fw}}$ because all of the latter first entered fresh water as elvers before engaging in one or more further inter-habitat movements as juveniles (Table 1). Relatively few elvers enter fresh water and then return to the estuary in the same year (as indicated by the smaller arrow in Fig. 3). In later years, those eels may either remain in the estuary/salt waters (Cairns et al. 2004) or return to fresh water (B. M. Jessop unpubl. data). In general, it is premature to assign proportions to migratory categories due to insufficient data. Lamson et al. (2006) classified habitat groups according to the proportion of occupancy in fresh water $(\mathrm{F})$, transition $(\mathrm{T})$, and salt water (S) after Age 1 yr. The F group is largely equivalent to the Fw group of B. W. Jessop (unpubl.) (definitions of habitat occupancy vary slightly), the S group to the Sw group, and the $\mathrm{T}$ group includes both $\mathrm{IH}_{\mathrm{Fw}}$ and $\mathrm{IH}_{\mathrm{Sw}}$ groups. A standard habitat classification scheme that accounts for the variety of eel habitat choices and migrational patterns would assist our understanding of eel biology and the comparison of studies. One possible scheme is that proposed by B. M. Jessop (unpubl.; Table 1). The division according to freshwater entrance as elver or juvenile has behavioural and survival implications in that the choice of habitat (salt water, fresh water) 
Table 1. Variability in habitat-use categories for American eels in eastern Canada based upon otolith Sr:Ca ratio patterns. fw: fresh water, sw: seawater. Category definitions provided under 'Habitat use'

\begin{tabular}{|c|c|c|}
\hline Category & Habitat use & Location (source) \\
\hline 1 & $\begin{array}{l}\text { Enter fw as an elver, remain in } \mathrm{fw} \\
\text { until capture or silvering (no inter- } \\
\text { habitat migration) }\end{array}$ & $\begin{array}{l}\text { East River, Chester, } \\
\text { Nova Scotia (Jessop } \\
\text { et al. 2004, 2006) }\end{array}$ \\
\hline 2 & $\begin{array}{l}\text { Enter fw as an elver, remain in fw for } \\
\geq 1 \text { yr before returning to sw for } \geq 1 \\
\text { yr, then returning to fw until capture }\end{array}$ & \\
\hline 3 & $\begin{array}{l}\text { Enter fw after } \geq 1 \text { yr in sw (juvenile), } \\
\text { then remain in fw until capture/sil- } \\
\text { vering (no inter-habitat migration) }\end{array}$ & \\
\hline 4 & $\begin{array}{l}\text { Enter fw after } \geq 1 \mathrm{yr} \text { in sw (juvenile), } \\
\text { then remain in fw for } \geq 1 \mathrm{yr} \text { before } \\
\text { returning to } \mathrm{sw} \text { for } \geq 1 \mathrm{yr} \text {, then } \\
\text { returning to fw before capture/ } \\
\text { silvering }\end{array}$ & \\
\hline SF & $\begin{array}{l}\text { Enter fw as elver, remain in fw until } \\
\text { capture }\end{array}$ & $\begin{array}{l}\text { Boughton River, } \\
\text { Prince Edward Island }\end{array}$ \\
\hline SB & $\begin{array}{l}\text { Remain in sw as elver, remain in sw } \\
\text { until capture }\end{array}$ & (Cairns et al. 2004) \\
\hline $\mathrm{SAB}$ & $\begin{array}{l}\text { Enter upper estuary as elver, possibly } \\
\text { with fw entrance, remain for }<2 \text { yr } \\
\text { before returning to sw (middle } \\
\text { estuary) until capture }\end{array}$ & \\
\hline 1 (FR) & $\begin{array}{l}\text { Enter fw as elver, remain in fw until } \\
\text { capture }\end{array}$ & $\begin{array}{l}\text { St. Jean River Quebec } \\
\text { (Daverat et al. 2006, }\end{array}$ \\
\hline $2(\mathrm{BR})$ & $\begin{array}{l}\text { Remain in sw as elver, remain in sw } \\
\text { until capture }\end{array}$ & $\begin{array}{l}\text { Thibault et al. } 2007 \mathrm{~b} \\
\text { category in paren- }\end{array}$ \\
\hline 3a $\left(\mathrm{A}_{\mathrm{BF}}\right)$ & $\begin{array}{l}\text { Remain in sw as elver, remain in } \mathrm{sw} \\
\text { for } \geq 2 \mathrm{yr} \text { before entering } \mathrm{fw} \text {, then } \\
\text { remain in fw until capture }\end{array}$ & theses) \\
\hline $3 b\left(\mathrm{~A}_{\mathrm{FB}}\right)$ & $\begin{array}{l}\text { Enter fw as elver, remain in fw for } \\
\text { undefined number of years, then } \\
\text { return to sw until capture }\end{array}$ & \\
\hline $3 \mathrm{C}\left(\mathrm{A}_{\mathrm{FBF}}\right)$ & $\begin{array}{l}\text { Enter fw as elver, return to sw for } \\
\text { undefined number of years, then } \\
\text { return to fw until capture }\end{array}$ & \\
\hline $3 d\left(A_{N D}\right)$ & $\begin{array}{l}\text { Fw-sw movement with no defined } \\
\text { pattern }\end{array}$ & \\
\hline $\mathrm{F}$ & $\begin{array}{l}\text { Fw residence after Age } 1 \text { yr until } \\
\text { capture }\end{array}$ & $\begin{array}{l}\text { Brackley-Covehead, } \\
\text { Prince Edward Island }\end{array}$ \\
\hline S & $\begin{array}{l}\text { Sw residence after Age } 1 \text { yr until } \\
\text { capture }\end{array}$ & (Lamson et al. 2006) \\
\hline $\mathrm{T}$ & $\begin{array}{l}\text { Inter-habitat migrants between fw } \\
\text { and sw }\end{array}$ & \\
\hline Fw & $\begin{array}{l}\text { Fw resident-enter fw as elver, } \\
\text { remain until silvering }\end{array}$ & B. M. Jessop (unpubl.) \\
\hline Sw & $\begin{array}{l}\text { Sw resident-no entrance to fw as } \\
\text { elver or juvenile, remain in sw until } \\
\text { silvering }\end{array}$ & \\
\hline $\mathrm{IH}_{\mathrm{Fw}}$ & $\begin{array}{l}\text { Enter fw as elver, remain in fw for } 0 \\
\text { (few elvers) to } \geq 1 \text { yr, then } \geq 1 \text { move- } \\
\text { ments of variable duration between } \\
\text { fw and sw before silvering }\end{array}$ & \\
\hline $\mathrm{IH}_{\mathrm{Sw}}$ & $\begin{array}{l}\text { Sw residence for } \geq 1 \mathrm{yr} \text {, enter } \mathrm{fw} \text { as } \\
\text { juvenile, then } 0 \text { (residence) to } \geq 1 \\
\text { movements between fw and sw } \\
\text { before silvering }\end{array}$ & \\
\hline
\end{tabular}

may be influenced by behavioural, physiological, and environmental conditions during glass eel/elver estuarine arrival (Edeline et al. 2005, 2006, Edeline 2007) and entrance as a juvenile may ultimately result in a greater contribution to the production of silver eels (Jessop et al. 2002). The $\mathrm{IH}_{\mathrm{fw}}$ and $\mathrm{IH}_{\mathrm{sw}}$ can readily be subdivided by age at, and frequency of, inter-habitat migration and percent freshwater/saltwater residence, but such subdivisions necessarily retain an element of arbitrariness unless some underlying biological basis can be found. Least arbitrary might be the subdivision into habitat residence groups based on $<$ or $>50 \%$ freshwater residence, which would define primarily freshwater or primarily estuarine residence.

\section{Criteria for determining habitat residence}

Otolith Sr:Ca-based determination of historical habitats (marine, estuarine, fresh water) and periods of habitat residence depends on the selection of habitat-separation values. Habitat separation Sr:Ca values may vary geographically and be set as a critical value, within a range of values (Table 2). Where a habitat separation criterion is not defined, habitat categories may be inferred from the $\mathrm{Sr}$ :Ca profile and mean values within a zone of interest (Cairns et al. 2004). Similar variability occurs for European and Japanese eel studies (e.g. Tsukamoto \& Arai 2001, Daverat \& Tomás 2006). Critical Sr:Ca values for habitat transitions are expected to vary among sites because of the influence of varying geological conditions on ambient fresh water $\mathrm{Sr}$ and Sr:Ca values, which may range widely, and fluvial estuaries may contain steep gradients in $\mathrm{Sr}$ :Ca values depending upon their mixing characteristics, which depend largely on freshwater Sr values and discharge (Kraus \& Secor 2004). The collection of ambient fresh water $\mathrm{Sr}$ and Sr:Ca values and knowledge of estuarine mixing gradients can assist the interpretation of otolith Sr:Ca transect patterns (Elsdon \& Gillanders 2004, Kraus \& Secor 2004). Few studies yet report such information (but see Jessop et al. 2002, 2006). The distinction between Sr:Ca values expressed as wt\% or as molar ratios, typically used for partition coefficients between ambient water and otolith $\mathrm{Sr}$ :Ca and other environmental relations, must be considered when comparing studies because $\mathrm{Sr}$ : Ca ratios based on wt $\%$ are about $2.19 \times$ higher than those based on molar values. 
River had a totally freshwater history (Jessop et al. 2002), as did $33 \%$ of yellow eels in the St. Jean River (excluding estuarine residents; Thibault et al. 2007b). The proportion of long-term freshwater residents increases with the distance migrated upstream (Daverat et al. 2006). Thus, freshwater residents comprised $92 \%$ of yellow eels ( $\mathrm{FR}$ and $\mathrm{A}_{\mathrm{BF}}$ ) in Sirois Lake, $80 \mathrm{~km}$ upstream on the St. Jean River (Thibault et al. 2007b), $71 \%$ in the relatively small (main stem $<20 \mathrm{~km}$ ) East River (Jessop et al. 2006), and 10 to $54 \%$ in ponds $<1 \mathrm{~km}$ from saltwater bays on northern PEI (Lamson et al. 2006) (Fig. 4). Inter-habitat migrant eels decreased correspondingly in abundance with distance upstream. Where dams prevent the upstream movement of eels larger than elvers, the proportion of freshwater residents in upstream ponds may be $100 \%$ (Cairns et al. 2004, Lamson et al. 2006).

Eels that remain in marine or estuarine waters after the elver stage may either remain in those habitats until maturation or may periodically move between salinity zones or into fresh water. Of the proportion that later enters fresh water as juveniles, some remain as freshwater residents until maturation while others become inter-habitat migrants. Thus, in the East River, of the $25 \%$ of silver eels that entered the river as juveniles, $31 \%$ remained resident in fresh water and $69 \%$ showed inter-habitat movement (Jessop et al. 2002). A lower proportion of yellow eels (29\%) may show interhabitat movement than do silver eels, perhaps due to a younger age structure (Jessop et al. 2006).

It is now clear that American eels do not follow an obligatory catadromous life cycle and may be considered facultatively catadromous with a variable euryhaline migratory component (Jessop et al. 2002, 2006, Cairns et al. 2004, Daverat et al. 2006, Lamson et al. 2006). European glass eels display an increased prefer-

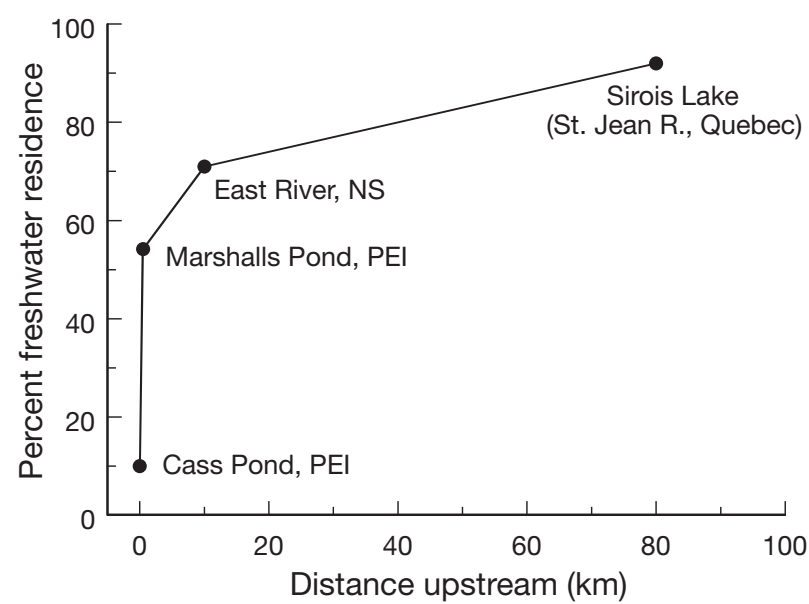

Fig. 4. Anguilla rostrata. Percentage of freshwater-resident American eels in relation to distance of sampling site upstream from the river mouth. NS: Nova Scotia; PEI: Prince Edward Island ence for brackish water habitat as the elver run progresses and fish condition declines (Edeline et al. 2006). However, the seasonal decline in American eel elver condition that occurs in northern latitudes (Jessop 1998, 2003) appears not to occur south of about Chesapeake Bay (Powles \& Warlen 2002, Sullivan et al. 2006, 'American eel YOY index analysis' B. M. Jessop unpubl.), indicating a possible geographic break in the influence of condition on elver habitat choice. The choice of migratory tactic by yellow eels appears not to depend on individual differences in length, sex, or age (Jessop et al. 2006, Thibault et al. 2007b) but rather on physiological conditions at particular life stages. Although European glass eels may increasingly prefer salt water as their body condition declines over a run (Edeline et al. 2006), yellow eels may act differently because small fresh water eels do not preferentially migrate to the estuary (Thibault et al. 2007b). The migratory patterns chosen by individual eels may be the cause, rather than the consequence, of their biological characteristics (Morrison et al. 2003).

\section{Inter-habitat migration frequency and duration}

After their first entrance to fresh water, whether as elver or juvenile eel, most inter-habitat migrant yellow eels make only one or 2 additional habitat switches: a return to the estuary for a variable period of time followed by a return to fresh water (a round trip) (Jessop et al. 2006). Thus, in the East River, $81 \%$ of inter-habitat migrant yellow eels undertook only a single round trip migration between estuary and river and $19 \%$ made 2 round trips. In comparison, $46 \%$ of silver eels made 1 round trip, $32 \%$ made 2 round trips, and $22 \%$ made 3 round trips. Thus, the total number of inter-habitat movements increased with age, as was also noted for yellow eels from a PEI pond (Lamson et al. 2006).

Round trip movements may occur within a year (spring, autumn) or extend over up to 4 yr (Thibault et al. 2007a, B. M. Jessop unpubl. data). The first habitat switch tends to occur at a young age, typically Ages 2 to 4 yr (range 1 to 7 ) in the St. Jean River (Thibault et al. 2007b) and Ages 3 to 5 yr (range 0 to 8), with a mean age of $3.4 \mathrm{yr}$ in the East River (B. M. Jessop unpubl. data).

The number of inter-habitat movements increases with age, with each inter-habitat migrant yellow eel averaging 1.9 (range 1 to 4 ) movements for 26 eels 4 to 20 yr old from 4 ponds on PEI (recalculated from Lamson et al. 2006) and 5.1 (range 2 to 10) movements from the East River for 28 eels 5 to 20 (mean 10.4) yr old (B. M. Jessop unpubl. data). Yellow eels that first entered the East River as elvers $(n=25)$ undertook a similar number of habitat shifts (mean 5.1, range 2 to 10 ) as did eels that entered the river as juveniles $(n=3$, mean 4.7 , 
range 2 to 6$)\left(F_{1,26}=0.09, p=0.77\right)$ (B. M. Jessop unpubl. data). The frequency (number of shifts/year, logarithmically transformed) of inter-habitat movements decreased linearly with increasing age $(\mathrm{n}=28$, $\mathrm{r}=-0.63, \mathrm{p}<0.001)$. Lamson et al. (2006) concluded that the number of inter-habitat shifts by eels varied among sites and increased in number, but not frequency, with age at 1 site (Cass Pond). All of the sites examined are within a limited latitudinal range and no conclusion can yet be made on whether the lifetime number or frequency (number per year) of inter-habitat movements changes with latitude. However, little variability occurs in number of movements within this narrow latitudinal range. Given that the female age at migration increases with increasing latitude $(\mathrm{n}=12, \mathrm{r}=$ 0.83, p < 0.001; B. M. Jessop unpubl. data), an increase in inter-habitat migration may occur with increasing latitude. Although only a portion of American eels become inter-habitat migrants, the occurrence of interhabitat movements throughout the continental lifespan implies an on-going reassessment of habitat suitability relative to body condition, while the decrease in frequency of movement with age suggests that the benefits of habitat change are most substantial at younger ages when growth is most rapid.

\section{Seasonality of inter-habitat transition}

Inter-habitat transitions, as well as other environmental stresses such as water temperature changes, starvation, handling, and normal migratory events, can cause growth checks in the otolith (Volk et al. 1999, Jessop et al. 2006). The detection of otolith growth checks and evaluation of seasonal patterns in inter-habitat movement by yellow eels-e.g. spring movements from river to estuary or autumn movements from estuary to river-via the analysis of otolith $\mathrm{Sr}$ :Ca patterns is useful but can be problematic. Otolith Sr:Ca values indicating a habitat transition (change across a threshold value separating fresh water and estuarine Sr:Ca values) must be correctly identified and precisely matched relative to the positions of annuli or other markers. About $36 \%$ of yellow eels from the East River exhibited otolith checks indicative of a habitat transition and $38 \%$ of habitat transition checks occurred be- tween the elver check and the first annulus. Most (57\%) otolith growth checks indicating a habitat transition occurred in the spring (represented by the first $33 \%$ of the distance between annuli; Jessop et al. $2006)$, followed by summer (27\%), and autumn (16\%). Misidentification of growth checks resulting from inter-habitat movements may lead to overestimation of eel age and underestimation of the frequency of inter-habitat movements while misattributing growth checks of other origin may overestimate inter-habitat movement.

Otolith Sr:Ca ratio and field observational data both indicate seasonal inter-habitat migrations by American eels. Interceptions of moving eels by fishing gears confirm the downstream migration in spring from freshwater wintering grounds to, presumably, estuarine summering grounds (Smith \& Saunders 1955, Medcof 1969). Traps set for Atlantic salmon Salmo salar smolts on the Bec-Scie River on Anticosti Island captured about 24000 downstream migrant American eels in the first 3 wk of June 1995 (Caron \& Raymond 1997) (Fig. 5). Rotary traps caught an estimated 15000 to 40000 eels (length range 123 to $640 \mathrm{~mm}$ ) migrating downstream in the St. Jean River in May/June (Caron et al. 2005), and a similar spring downstream run of eels was also evident in the Restigouche River (Fig. 5). Micro-tagging and acoustic tracking of yellow eels in the St. Jean River found that some spring downstream migrants that feed during summer in the estuary return to the river to overwinter (Thibault et al. 2007a). A quantitatively small, upstream migration in spring by small (65 to $240 \mathrm{~mm}$ ) juvenile American eels occurs in

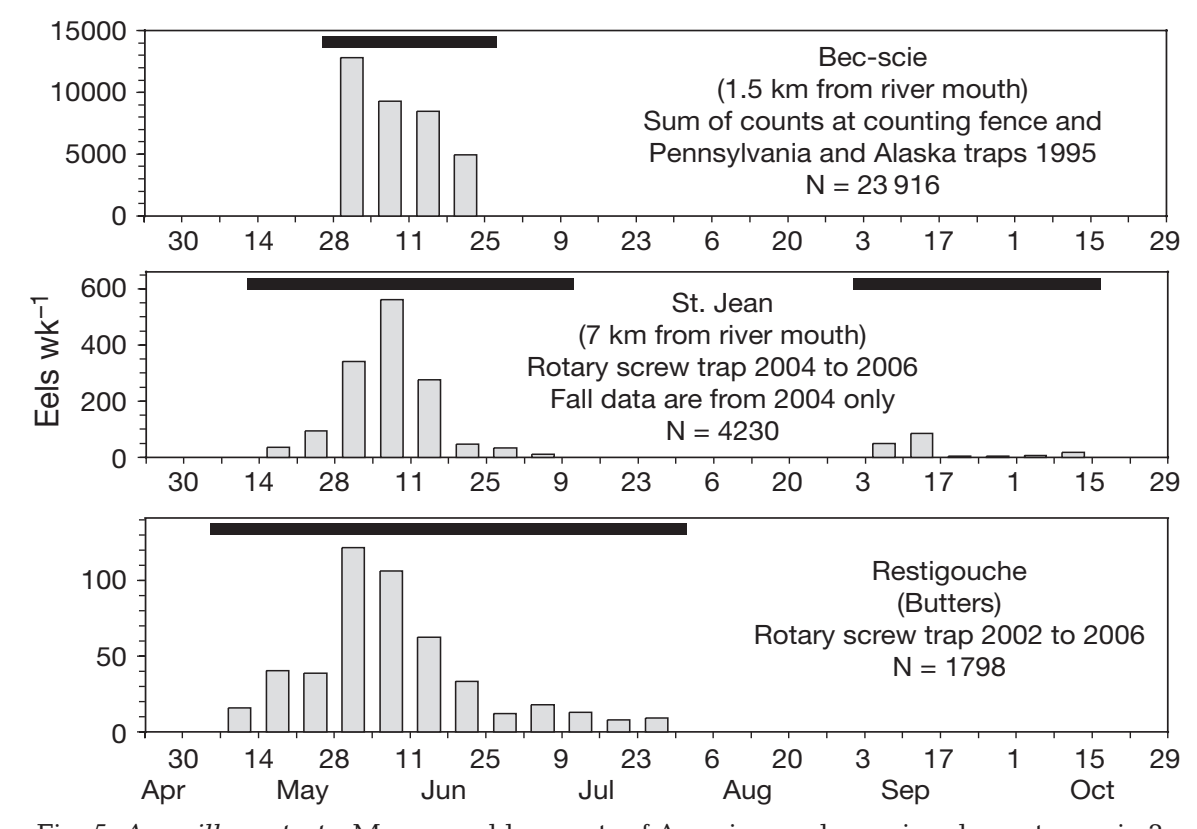

Fig. 5. Anguilla rostrata. Mean weekly counts of American eels moving downstream in 3 Gulf of St. Lawrence rivers (Bec-scie, St. Jean, Restigouche). Horizontal bars indicate weeks for which data are available 
the East River (Jessop 2003). The geographic ubiquity of estuarine to freshwater migrations in spring by small, juvenile eels is unknown. Autumnal estuarine to freshwater migrations may also occur (Smith \& Saunders 1955, Jessop 1987).

A pattern of annual spring downstream and autumn upstream movements by varying portions of the eel stock of a river system suggests migrations between freshwater wintering and estuarine feeding areas, but it is uncertain how prevalent this pattern is in the American eel. American eels commonly winter in mud under ice-covered estuaries and bays with brackish to full-strength salt water (Cairns et al. 2007). Wintering migrations to fresh water may not be forced by low winter temperatures but perhaps by the relative availability of suitable over-wintering habitat and possibly reduced predation. Daverat et al. (2006) suggest that the pattern of habitat use by anguillid eels is determined by environmental conditions, including productivity and inter- and intra-specific competition, in a bet-hedging strategy such that the proportion of saltwater residency increases at northern latitudes. Edeline (2007) offers a more detailed analysis of the evolution of anguillid diadromy and concludes that eel migration represents a trade-off between the search for productive habitats and shifts to less productive, lower density habitats where competition and predation may be less.

The elemental composition at the otolith edge of migrant American eels may differ from that expected from the habitat that they are captured in, perhaps due to the lag in manifestation of habitat change within the otolith, particularly for older, slower growing eels (Jessop et al. 2002). Growth in eel length and otoliths is minimal over the winter at northern latitudes due to coldinduced torpidity, to a degree that fresh water over-wintering may not be recorded in the otoliths of seasonally migrant yellow eels (Thibault et al. 2007b). Consequently, the proportion of brackish water residents and the frequency of inter-habitat migration may be underestimated at northern latitudes. This conclusion applies only to the extent that suitable estuarine and associated marine habitats occur in and near the lower reaches of a river system and inter-habitat migration occurs. Many Canadian Atlantic coastal and northern Gulf of St. Lawrence rivers have limited estuarine/marine habitat.

Although both yellow and silver eels captured in fresh water during downstream migrations may have $\mathrm{Sr}$ : Ca ratios near the otolith edge suggestive of estuarine resi- dence, spring downstream migrant yellow eels differ biologically from fall migrant silver eels. It still remains unclear why a substantial proportion $-41 \%$ of 64 eels in the East River (Jessop et al. 2002), and $60 \%$ of 43 eels in the Castors River (B. M. Jessop unpubl. data) - of downstream migrant silver eels with a history of inter-habitat migration should have $\mathrm{Sr}$ :Ca ratio values at the otolith edge indicative of estuarine residence, yet be caught upriver (suggesting that they entered fresh water for a relatively brief period before beginning a downstream spawning migration) (Fig. 6). Of the remaining inter-habitat migrants, a few had entered fresh water at least several months earlier, but most had entered one or more years earlier. Potential explanations include (1) a technical artefact of otolith preparation, such as discussed and rejected by Jessop et al. (2002) and Thibault et al. (2007b), (2) chance, in that some eels returning to the river from the estuary were maturing and became sufficiently mature after a relatively short period that they began the spawning migration with maturing resident eels, (3) eels that had originally entered fresh water as elvers and juveniles before undertaking inter-habitat migrations needed to return to freshwater to reorient their migratory 'internal compass' relative to their stream position during their early life.

The relative frequency of such 'farewell visits' to the river by silver eels with a history of inter-habitat migra-

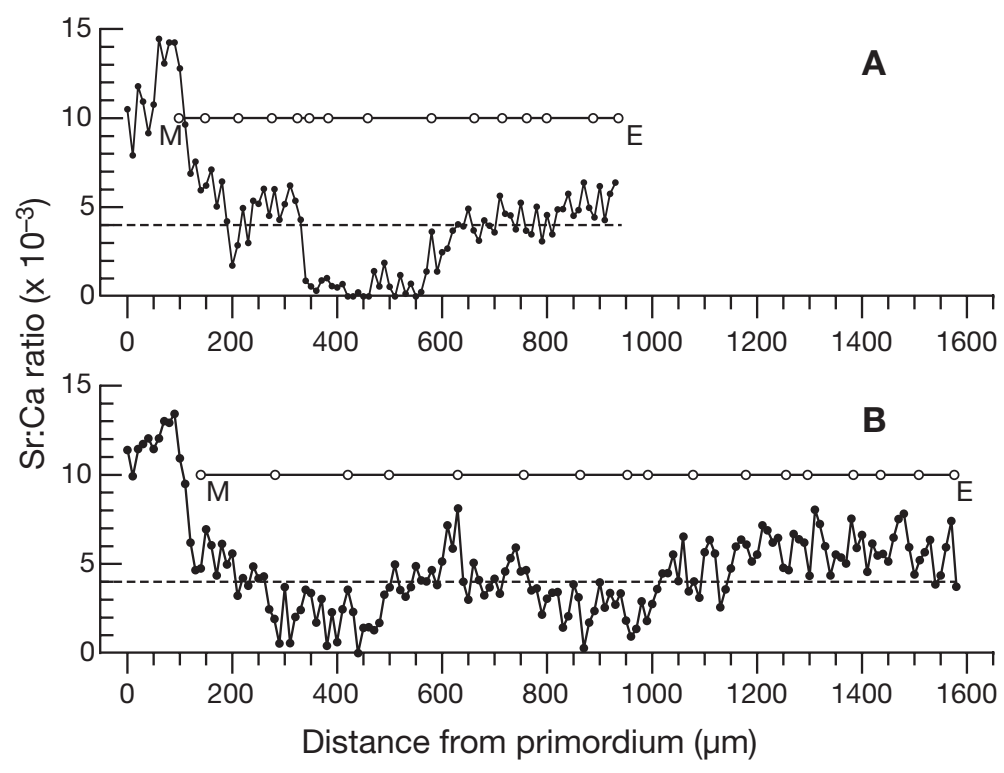

Fig. 6. Anguilla rostrata. Sr:Ca ratios of 2 silver-phase American eels from the Castors River, Newfoundland, caught about $11 \mathrm{~km}$ upstream from saltwater and showing (A) no evidence (closed circles) of freshwater residence at the otolith edge (female, $494 \mathrm{~mm}$ TL, Age $15 \mathrm{yr}$ ) and (B) recent entrance to fresh water (female, $665 \mathrm{~mm} \mathrm{TL}$, Age $13 \mathrm{yr}$ ) relative to the $4.0 \times 10^{-3}$ habitat transition criterion (dashed line). M: metamorphosis check, E: otolith edge, open circles: annuli 
tion implies that more than chance is involved. A testable hypothesis with supportive evidence is that, prior to beginning their spawning migration, estuarine-resident inter-habitat migrant eels return to the location where they first imprinted the geomagnetic characteristics of their 'home' stream. American and European eels can return to 'home' waters after displacement from up to several hundred kilometres (Vladykov 1971, Tesch 1977) and are able to sense the earth's magnetic field (Tesch 1977, Souza et al. 1988), as are Japanese eels (Nishi et al. 2004). In combination, these abilities suggest that eels may potentially use magnetic map navigation (Freake et al. 2006). Magnetic field detection and orientation involves magnetic receptor cells in nasal olfactory lamellae that contain magnetite crystals of biogenic origin (Diebel et al. 2000). Magnetosensitivity is present in Japanese glass eels (Nishi \& Kawamura 2005), American elvers (Rommel \& McCleave 1973), and probably European glass eels because larger European eels have magnetite particles within the skull (Hanson et al. 1984). Stocked eels have been hypothesized to lack the opportunity to imprint the directional cues necessary for migration (Westin 2003) or perhaps have imprinted directional cues from their initial freshwater arrival that are inappropriate to the transplant location. Elvers that enter fresh water at continental arrival may thus establish a geomagnetic reference early in their continental residence from which they could reverse the 'memorized' geomagnetic map and return to the spawning ground. Elevated concentrations of thyroid hormones such as occur during the elver stage are associated with migratory behaviour and habitat selection (Edeline et al. 2004) and perhaps also with geographic position imprinting (Lucas \& Baras 2001). Silver migrants from the upper reaches of a river would necessarily pass through a downstream reference zone but interhabitat migrants downstream of the zone may have to return to fresh water and re-orient within the reference zone. Silver Japanese and European eels of estuarine and marine habitat historic residence can begin their spawning migration from those habitats (Tzeng et al. 2000, Kotake et al. 2003) and it is likely, but unproven, that American eels may do so.

\section{Habitat-specific growth rates}

American eel length (and otolith) growth rates increase with increasing habitat salinity (marine > estuarine $>$ fresh water) and water temperature and vary widely among sites (Morrison et al. 2003, Cairns et al. 2004, Jessop et al. 2004, Lamson 2006). Lamson (2006) noted that eels grew faster $\left(98.2 \mathrm{~mm} \mathrm{yr}^{-1}, \mathrm{SD}=33.4, \mathrm{n}=\right.$ 33) in the marine bays of the north shore of PEI than in freshwater ponds (45.2 $\mathrm{mm} \mathrm{yr}^{-1}, \mathrm{SD}=18.2, \mathrm{n}=27$ ), while inter-habitat migrants grew at intermediate rates (60.5 $\left.\mathrm{mm} \mathrm{yr}^{-1}, \mathrm{SD}=26.2, \mathrm{n}=26\right)$. Eels from the East River with $<50 \%$ of their growth in fresh water (primarily estuarine residents) grew more rapidly $(23.4 \mathrm{~mm}$ $\mathrm{yr}^{-1}, 95 \% \mathrm{CI}: 21.2$ to $24.7 \mathrm{~mm} \mathrm{yr}^{-1}, \mathrm{n}=31$ ) than did those with $>50 \%$ of their growth in fresh water $(20.7 \mathrm{~mm}$ $\mathrm{yr}^{-1}, 95 \%$ CI: 18.8 to $21.8 \mathrm{~mm} \mathrm{yr}^{-1}, \mathrm{n}=30$ ) (Jessop et al. 2004) and were larger at silvering, consistent with the hypothesis that size is the primary factor inducing eel migration (Oliveira 1999). In both freshwater and saline habitats, female eels grew more rapidly than did male eels (Jessop et al. 2004). Edeline \& Elie (2004) concluded that higher growth rates of glass eels in more productive marine environments are unrelated to the higher availability of food and result from a greater appetite, perhaps due to a hormonal mechanism.

The faster growth of eels from PEI relative to eels from the East River can be attributed to differences in water temperature and productivity. Summer water temperatures $\left({ }^{\circ} \mathrm{C}\right)$ in PEI are typically in the low-to-mid 20s (Lamson 2006), close to the optimum for eel growth (22 to $26.5^{\circ} \mathrm{C}$ ) (Tesch 1977 ). They are also highly productive, particularly the saltwater bays (Lamson 2006). In the East River, water temperatures averaged $20^{\circ} \mathrm{C}$ (range 15 to $23^{\circ} \mathrm{C}$ ) between mid-June and midSeptember and productivity is low due to acid stress (Jessop 2000).

\section{Inter-habitat migration effects on growth rate and residence period estimates}

The evaluation of growth rate and residence period in a habitat is simple for eels residing in a single salinity zone but the situation is more complex for eels that migrate periodically between freshwater and saltwater habitats. If otolith growth rate varies among habitats, then a given otolith transect proportion may not reflect the time spent in each habitat (Jessop et al. 2006). For inter-habitat migrant yellow eels from the East River, the mean proportion of residence time in fresh water slightly $(2.9 \%)$, but significantly, exceeded the proportion of otolith growth in fresh water based upon detailed measurements and comparisons of the temporal patterns in habitat residence and annual growth (Jessop et al. 2007). The magnitude of the effect was small, perhaps of little biological consequence, and otolith growth period and habitat residency period can be considered functionally equivalent. However, where large differences occur between growth rates in different habitats, the effect may be important. Habitat-specific growth rates should be used for detailed examinations of inter-habitat migration and residency. 


\section{Technical issues}

Otolith Sr:Ca ratios show substantial variability even within a habitat. Sr:Ca values that are outliers from a habitat norm are not uncommon (Jessop et al. 2007). Evidence that such outliers represent a brief habitat transition is equivocal but the number of $\mathrm{Sr}$ :Ca values and their degree of departure from the habitat norm or critical value necessary to indicate a habitat movement remains to be resolved. The issue depends on the duration of seasonal movements between habitats, the rate of otolith growth, rate of element incorporation, and the microprobe spot size (Kraus \& Secor 2003, Jessop et al. 2006). If outliers represent true habitat transitions, ignoring them will underestimate the frequency of inter-habitat movement, while unnecessarily counting them (e.g. if they are technical artefacts) overestimates such movements (Kotake et al. 2003, Zimmerman \& Nielsen 2003). A minimum of $2 \mathrm{Sr}$ :Ca values beyond a critical value was used by Jessop et al. (2006) to estimate the percent habitat occupancy and frequency of, as well as age at, inter-habitat movements. Estimating the percent habitat occupancy as the proportion of $\mathrm{Sr}$ : Ca values that differ from a critical transition value (Jessop et al. 2002, 2004, Lamson et al. 2006) ignores outliers and their potential as indicators of brief inter-habitat movements. Whether outliers are included or excluded makes little difference when estimating percent habitat occupancy (Jessop et al. 2007).

Smoothing of the Sr:Ca data series to reduce variability assumes that singleton or short series of data points different from the critical value do not represent a habitat transition. A variety of smoothing methods has been used, including 5-point (Lamson et al. 2006) and 9-point moving averages (Cairns et al. 2004), and LOWESS (locally weighted robust regression) with a span (proportion in the moving window of the total number of data points) of 0.5 to 0.7 , which is sufficient to minimize the influence of single or multiple outliers (B. M. Jessop unpubl. data). No smoother span or method may be uniformly best for all otolith $\mathrm{Sr}$ :Ca transects.

\section{SUMMARY}

The analysis of Sr:Ca values in the otoliths of American eels has revealed a great complexity in migratory behaviours, habitat residency patterns, and habitatrelated growth effects that require consideration when interpreting life history and evaluating population size and structure. Further research is required to determine the extent to which these migratory behaviours occur over the geographic range of the American eel and their relation to the relative abundance of eels in fresh-, estuarine-, and salt waters. A simple yet com- prehensive standardized habitat migratory classification scheme, perhaps as proposed here, would facilitate the interpretation of, and comparison between, otolith microchemistry studies on eels. The determination of ambient fresh water $\mathrm{Sr}$ :Ca values is essential for the proper interpretation of habitat residence based on otolith $\mathrm{Sr}: \mathrm{Ca}$ values, and knowledge of mixing gradients for estuarine studies would be very useful. Resolution of technical issues related to the interpretation of otolith $\mathrm{Sr}$ :Ca patterns is necessary if detailed evaluations of migratory patterns are to be relied upon.

Acknowledgements. We are grateful for financial support from the Natural Sciences and Engineering Research Council of Canada, Ministère de l'Agriculture, des Pêcheries et de l'Alimentation du Québec, Ministère des Ressources Naturelles et de la Faune du Québec, and the National Science Council, ROC. We thank F. Caron, J. Dodson, Y. Iizuka, H. Lamson, D. MacPherson, and J. Shiao for collaboration and support.

\section{LITERATURE CITED}

Cairns DK, Shiao JC, Iizuka Y, Tzeng WN, MacPherson CD (2004) Movement patterns of American eels in an impounded watercourse, as indicated by otolith microchemistry. N Am J Fish Manag 24:452-458

Cairns DK, Omilusik DL, Leblanc PH, Atkinson EG, Moore DS, McDonald N (2007) American eel abundance indicators in the southern Gulf of St. Lawrence. Can Data Rep Fish Aquat Sci 1192:1-119

- Campana SE (1999) Chemistry and composition of fish otoliths: pathways, mechanisms and applications. Mar Ecol Prog Ser 188:263-297

Caron F, Raymond C (1997) Rapport d'opération de la rivière Bec-Scie en 1995. Ministère de l'Environnement et de la Faune, Direction de la faune et des habitats, Service de la faune aquatique, Quebec

Caron F, Fournier D, Cauchon V (2005) Travaux de recherché sur le saumon des rivières Saint-Jean et de la Trinité en 2004. Ministère des Ressources naturelles et de la Faune, Direction de la recherché sur la faune, Quebec

Daverat F, Tomás J (2006) Tactics and demographic attributes in the European eel Anguilla anguilla in the Gironde watershed, SW France. Mar Ecol Prog Ser 307:247-257

$>$ Daverat F, Tomás J, Lahaye M, Palmer M, Elie P (2005) Tracking continental habitat shifts of eels using otolith $\mathrm{Sr} / \mathrm{Ca}$ ratios: validation and application to the coastal, estuarine and riverine eels of the Gironde-Garonne-Dordogne watershed. Mar Freshw Res 56:619-627

Daverat F, Limburg KE, Thibault I, Shiao JC and others (2006) Phenotypic plasticity of habitat use by 3 temperate eel species, Anguilla anguilla, A. japonica and A. rostrata. Mar Ecol Prog Ser 308:231-241

Diebel CE, Proksch R, Green CR, Neilson P, Walker MM (2000) Magnetite defines a vertebrate magnetoreceptor. Nature 406:299-302

Edeline E (2007) Adaptive phenotypic plasticity of eel diadromy. Mar Ecol Prog Ser 341:229-232

Edeline E, Elie P (2004) Is salinity choice related to growth in juvenile eel Anguilla anguilla. Cybium 28:77-82

Edeline E, Dufour S, Briand C, Fatin D, Elie P (2004) Thyroid status is related to migratory behaviour in Anguilla 
anguilla glass eels. Mar Ecol Prog Ser 282:261-270

Edeline E, Dufour S, Elie P (2005) Role of glass eel salinity preference in the control of habitat selection and growth plasticity in Anguilla anguilla. Mar Ecol Prog Ser 304: 191-199

Edeline E, Lambert P, Rigaud C, Elie P (2006) Effects of body condition and water temperature on Anguilla anguilla glass eel migratory behaviour. J Exp Mar Biol Ecol 331: 217-225

Elsdon TS, Gillanders BM (2004) Fish otolith chemistry influenced by exposure to multiple environmental variables. J Exp Mar Biol Ecol 313:269-284

Francis RICC (1990) Back-calculation of fish length: a critical review. J Fish Biol 36:883-902

Freake MJ, Muheim R, Phillips JB (2006) Magnetic maps in animals: a theory comes of age? Q Rev Biol 81:327-347

Hanson M, Wirmark G, Öblad M, Strid L (1984) Iron-rich particles in European eel (Anguilla anguilla L). Comp Biochem Physiol A 79:311-316

Helfman GS, Facey DE, Hales LS Jr, Bozeman EL Jr (1987) Reproductive ecology of the American eel. In: Dadswell MJ, Klauda RJ, Moffitt CM, Saunders RL, Rulifson RA, Cooper JE (eds) Common strategies of anadromous and catadromous fishes. Am Fish Soc Symp 1: 42-56

Jessop BM (1987) Migrating American eels in Nova Scotia. Trans Am Fish Soc 116:161-170

> Jessop BM (1998) Geographical and seasonal variation in biological characteristics of American eel elvers in the Bay of Fundy area and on the Atlantic coast of Nova Scotia. Can J Zool 76:2172-2185

Jessop BM (2000) Estimates of population size and instream mortality rate of American eel elvers in a Nova Scotia river. Trans Am Fish Soc 129:514-526

Jessop BM (2003) The run size and biological characteristics of American eel elvers in the East River, Chester, Nova Scotia, 2000. Can Tech Rep Fish Aquat Sci: 2444

Jessop BM, Shiao JC, Iizuka Y, Tzeng WN (2002) Migratory behaviour and habitat use by American eels Anguilla rostrata as revealed by otolith microchemistry. Mar Ecol Prog Ser 233:217-229

Jessop BM, Shiao JC, Iizuka Y, Tzeng WN (2004) Variation in the annual growth, by sex and migration history, of silver American eels Anguilla rostrata. Mar Ecol Prog Ser 272:231-244

Jessop BM, Shiao JC, Iizuka Y, Tzeng WN (2006) Migration of juvenile American eels Anguilla rostrata between freshwater and estuary, as revealed by otolith microchemistry. Mar Ecol Prog Ser 310:219-233

Jessop BM, Shiao JC, Iizuka Y, Tzeng WN (2007) Effects of inter-habitat migration on the evaluation of growth rate and habitat residence of American eels Anguilla rostrata. Mar Ecol Prog Ser 342:255-263

Kotake A, Arai T, Ozawa T, Nojima S, Miller MJ, Tsukamoto $\mathrm{K}$ (2003) Variation in migratory history of Japanese eels, Anguilla japonica, collected in coastal waters of the Amakusa Islands, Japan, inferred from otolith Sr/Ca ratios. Mar Biol 142:849-854

Kraus RT, Secor DH (2003) Response of otolith Sr:Ca to a manipulated environment in young American eels. In: Dixon DA (ed) Biology, management, and protection of catadromous eels. Am Fish Soc Symp 33:79-85

Kraus RT, Secor DH (2004) Incorporation of strontium into otoliths of an estuarine fish. J Exp Mar Biol Ecol 302:85-106

Lamson HM (2006) Movement patterns and growth of American eels (Anguilla rostrata) between salt and fresh water, based on otolith microchemistry. MSc thesis, Univ New Brunswick, Fredericton
Lamson HM, Shiao JC, lizuka Y, Tzeng WN, Cairns DK (2006) Movement patterns of American eels (Anguilla rostrata) between salt- and freshwater in a coastal watershed, based on otolith microchemistry. Mar Biol 149: 1567-1576

Lucas MC, Baras E (2001) Migration of freshwater fishes. Blackwell Science, Oxford

Medcof JC (1969) Fishermen's reports of freshwater and saltwater migrations of Nova Scotia eels (Anguilla rostrata). Can Field Nat 83:132-138

Morrison WE, Secor DH, Piccoli PM (2003) Estuarine habitat use by Hudson River American eels as determined by otolith strontium:calcium ratios. In: Dixon DA (ed) Biology, management, and protection of catadromous eels. Am Fish Soc Symp 33:87-100

Nishi T, Kawamura G (2005) Anguilla japonica is already magnetosensitive at the glass eel phase. J Fish Biol 67: 1213-1224

Nishi T, Kawamura G, Matsumoto K (2004) Magnetic sense in the Japanese eel Anguilla japonica as determined by conditioning and electrocardiography. J Exp Biol 207: 2965-2970

Northcote TG (1978) Migratory strategies and production in freshwater fishes. In: Gerking SD (ed) Ecology of freshwater production. Blackwell, Oxford, p 326-359

Northcote TG (1984) Mechanisms of fish migration in rivers. In: McCleave JD, Dodson JJ, Neill WH (eds) Mechanisms of migration in fishes. Plenum, New York, p 317-355

Oliveira K (1996) Field validation of annular growth rings in the American eel, Anguilla rostrata, using tetracyclinemarked otoliths. Fish Bull (Wash DC) 94:186-189

Oliveira K (1999) Life history characteristics and strategies of the American eel, Anguilla rostrata. Can J Fish Aquat Sci 56:795-802

Powles PM, Warlen SM (2002) Recruitment season, size, and age of young American eels (Anguilla rostrata) entering an estuary near Beaufort, North Carolina. Fish Bull (Wash DC) 100:299-306

Rommel SA Jr, McCleave JD (1973) Sensitivity of American eels (Anguilla rostrata) and Atlantic salmon (Salmo salar) to weak electric and magnetic fields. J Fish Res Board Can 30:657-663

Smith WM, Saunders JW (1955) The American eel in certain fresh waters of the Maritime Provinces of Canada. J Fish Res Board Can 12:238-269

Souza JJ, Poluhowich JJ, Guerra RJ (1988) Orientation response of American eels, Anguilla rostrata, to varying magnetic fields. Comp Biochem Physiol A 90:57-61

Sullivan MC, Able KW, Hare JA, Walsh HJ (2006) Anguilla rostrata glass eel ingress into two, U.S. east coast estuaries: patterns, processes and implications for adult abundance. J Fish Biol 69:1081-1101

Tesch FW (1977) The eel: biology and management of anguillid eels. Chapman \& Hall, London

Thibault I (2006) Étude du comportement migratoire de l'anguille d'Amérique (Anguilla rostrata) dans la rivière Saint-Jean (Gaspé). MS thesis, Laval University, Quebec

Thibault I, Dodson JJ, Caron F (2007a) Yellow stage American eel movements determined by microtagging and acoustic telemetry in the St. Jean River watershed, Gaspé (Quebec, Canada). J Fish Biol 71:1095-1112

Thibault I, Dodson JJ, Caron F, Tzeng WN, Iizuka Y, Shiao JC (2007b) Facultative catadromy in American eels: testing the conditional strategy hypothesis. Mar Ecol Prog Ser 344:219-229

Tsukamoto K, Arai T (2001) Facultative catadromy of the eel Anguilla japonica between freshwater and seawater 
habitats. Mar Ecol Prog Ser 220:265-276

Tzeng WN (1996) Effects of salinity and ontogenetic movements on strontium:calcium ratios in the otoliths of the Japanese eel, Anguilla japonica Temminck and Sclegel. J Exp Mar Biol Ecol 199:111-122

Tzeng WN, Wang CH, Wickström H, Reizenstein M (2000) Occurrence of the semi-catadromous European eel Anguilla anguilla (L.) in Baltic Sea. Mar Biol 137:93-98

Vladykov VD (1971) Homing of the American eel, Anguilla rostrata, as evidenced by returns of transplanted tagged

Editorial responsibility: Leif Asbjørn Vøllestad, Oslo, Norway eels in New Brunswick. Can Field Nat 85:241-248

Volk EC, Schroeder SL, Grimm JJ (1999) Otolith thermal marking. Fish Res 43:205-219

$>$ Westin L (2003) Migration failure in stocked eels Anguilla anguilla. Mar Ecol Prog Ser 254:307-311

Zimmerman CE, Nielsen RL (2003) Effect of analytical conditions in wavelength dispersive electron microprobe analysis on the measurement of strontium-to-calcium ( $\mathrm{Sr} / \mathrm{Ca}$ ) ratios in otoliths of anadromous salmonids. Fish Bull (Wash DC) 101:712-718

Submitted: July 20, 2007; Accepted: October 29, 2007

Proofs received from author(s): January 10, 2008 